\section{Healthcare professionals' awareness, knowledge, attitudes, perceptions and beliefs about Ebola at Gondar University Hospital, Northwest Ethiopia: a cross-sectional study}

\author{
Tamrat Befekadu Abebe, ${ }^{1}$ \\ Akshaya Srikanth Bhagavathula, ${ }^{1}$ \\ Yonas Getaye Tefera, ${ }^{1}$ Akram Ahmad, ${ }^{2}$ \\ Muhammad Umair Khan, ${ }^{2}$ Sewunet \\ Admasu Belachew, ${ }^{1}$ Brandon Brown, ${ }^{3}$ \\ Tadesse Melaku Abegaz ${ }^{1}$ \\ ${ }^{1}$ Department of Clinical Pharmacy, \\ University of Gondar-College of Medicine \\ and Health Sciences, School of Pharmacy, \\ Gondar, Ethiopia; ${ }^{2}$ Department of Clinical \\ Pharmacy, UCSI University, Kuala \\ Lumpur, Malaysia; ${ }^{3}$ Center for Healthy \\ Communities, Division of Clinical \\ Sciences, UCR School of Medicine, \\ Riverside, CA, USA
}

\section{Abstract}

A poor understanding of Ebola Virus Disease (EVD) among Health Care Professionals (HCPs) may put our lives at risk. We aimed to assess the awareness, knowledge, attitudes, perceptions, beliefs of HCPs towards Ebola at Gondar University Hospital (GUH) in Northwest Ethiopia. We conducted a hospital based, cross-sectional survey among 245 randomly selected HCPs working at GUH from August-October, 2015. A validated, self-administered questionnaire was used to collect the data. We calculated descriptive statistics with $\mathrm{P}<0.05$ being statistically significant. Of the 245 participants, 211 (86.1\%) completed the study. The majority had heard about EVD and used news media (62\%) as a source of information. Still, many were afraid of getting EVD (56.4\%; $\mathrm{P}=0.001$ ). A significant number of HCPs thought EVD can cause paralysis like polio (45\%) and can be treated with antibiotics (28.4\%). In addition, $46.4 \%$ of the HCPs felt anger or fear towards Ebola infected patients $(\mathrm{P}=0.006)$. We identified poor knowledge and negative incorrect beliefs among doctors and allied health professionals. There is a need for intensive training for all HCPs reduce EVD risk.

\section{Introduction}

Ebola virus disease (EVD) is an acute contagious viral hemorrhagic fever caused by the
Filoviridae family. The recent 2014 outbreak in West Africa was caused by the Zaire strain which was associated with human and nonhuman transmission and exhibited high mortality rates (25-90\%), 1,2 though this was not the first outbreak of EVD. Multiple outbreaks occurred during 1976 and 2014 in Sudan, Uganda, Democratic republic of Congo, and other West African countries affecting thousands of civilians. On August 8, 2014, the World Health Organization (WHO) declared an international emergency in West Africa (Guinea, Liberia, Sierra Leone, and Nigeria) for the Ebola outbreak. ${ }^{3}$ However, the incidence of EVD among healthcare professionals (HCPs) was 103-folds higher than general population. ${ }^{4}$ With a rare mode of transmission from unknown reservoirs and infected animals, EVD is transmitted via body fluids, direct human-to-human contact, and nosocomial transmissions. ${ }^{5}$ The incubation period of EVD is 2 to 21 days with the early symptoms similar to malaria and influenza. EVD patients also develop vomiting, diarrhea, pain and other symptoms, often leading to death within two weeks. EVD constituted a major public health problem in sub-Saharan Africa, ${ }^{6}$ as Ebola affected countries were extremely poor with weak healthcare infrastructure. National and international health workers were also infected while treating EVD patients. By May 2015, the WHO reported that nearly two-thirds of infected healthcare workers working in West Africa died and this disproportionately impacted and traumatized the health workforce by Ebola. ${ }^{7}$ Strict precautionary measures at Ebola treatment facilities and public education has decreased its incidence thereafter.

The provision of appropriate sensitization (awareness-raising) training by governmental and non-governmental organizations to scale up knowledge, attitudes and preventive practices were initiated globally to counter EVD. The Federal Ministry of Health $(\mathrm{FMoH})$ in Ethiopia declared Ebola was not present in the country, but the fear of Ebola hovered across Ethiopia. However, Ethiopian FMoH has taken key interventions to strengthen preparedness of health workforce by training the HCPs, increasing public awareness, screening and monitoring of travelers at airports and land crossing areas. This took place all over Ethiopia to tackle EVD. ${ }^{8}$ In several instances, EVD misunderstandings of HCPs delayed controlling efforts to provide necessary treatment. Early determination of knowledge, attitudes and perceptions (KAP) of HCPs is important to provide appropriate interventions. A poor been no study conducted in Ethiopia examining the KAP of EVD. Therefore, we aimed to assess the awareness, KAP and beliefs around Ebola of HCPs working in Gondar University Hospital (GUH), Northwest Ethiopia.
Correspondence: Tamrat Befekadu Abebe, Department of Clinical Pharmacy, University of Gondar-College of Medicine and Health Sciences, School of Pharmacy, P.0. Box 196, Gondar, Ethiopia.

Tel.: +251.913.791302 - Fax: +251.58 .114 .1240$

E-mail: befekadutamrat@gmail.com

Key words: Attitudes, Ebola Virus Disease, Health Care Professionals, Knowledge, Ethiopia.

Contributions: TBA and ASB: contributed to the design, conducted the initial analysis and drafted the initial manuscript, as well as commented on the final draft. YGT and SAB: contributed to the data collection of the study and data entry. TMA and ASB: conducted the statistical analysis and wrote the final manuscript. $\mathrm{AA}$, MUK and $\mathrm{BB}$ : edited the final manuscript.

Conflict of interest: the authors declare no potential conflict of interest.

Received for publication: 29 June 2016. Revision received: 29 August 2016.

Accepted for publication: 30 November 2016 .

This work is licensed under a Creative Commons Attribution NonCommercial 4.0 License (CC BYNC 4.0).

(C) Copyright T.B. Abebe et al., 2016

Licensee PAGEPress, Italy

Journal of Public Health in Africa 2016; 7:570

doi:10.4081/jphia.2016.570

\section{Materials and Methods}

This study was conducted in Gondar city located in the Amhara region, northwest part of Ethiopia. It is located approximately 738 kilometer from the capital city Addis Ababa and also a border city to North Sudan (Metema $197 \mathrm{~km}$ ). The estimated population of Gondar is approximately 206,987 with 98,085 men and 108,902 women. ${ }^{9}$

\section{Study design}

An institution-based cross-sectional was conducted from August-October 2015 among healthcare professionals (HCPs), including doctors (general practitioners, residents), nurses (staff nurses and ward nurses), pharmacists (clinical pharmacists, hospital pharmacists and druggists) and others (midwifery, physiotherapy, and laboratory) working in Gondar University Hospital (GUH). GUH is the largest funded multidisciplinary specialized teaching referral hospital. With a bed capacity of 550, GHU serves more than 2 million people living in and around Gondar. A total of 500 registered HCPs working in GUH were included.

\section{Sample size}

One out of every two HCPs working in the 
hospitals were randomly selected to obtain diverse opinions during their spare time and to reach our target sample size of 245 HCPs. Simple randomization technique using computer-generated random numbers (www.graphpad.com) was used to generate the schedule for complete randomness. Data was cross-checked to ensure no HCPs were selected twice.

\section{Content of the study questionnaire}

A validated self-administered questionnaire was developed after a thorough literature review using the keywords: ${ }^{10-16}$ Ebola virus disease OR Ebola hemorrhagic fever OR Infectious disease OR Awareness OR KAP. The drafted questionnaire was modified to suit the local settings. The questionnaire was pilot tested among $10 \%$ of the sample size (health faculties) and open-ended questions were limited to reduce information bias. A 33 -item closeended questionnaire was used for the data collection and took approximately 20 minutes to complete (Suppl 1). The questionnaire was divided into six parts including sociodemographic details (3 items), awareness of EVD (3 items) and source of information (1 item), knowledge regarding EVD (5items) and symptoms of EVD effected patients (1 item), different modes of transmission through direct contacts, perceptions towards EVD effected patients (7 statements/4-point likert scale, beliefs (5 items) and attitudes towards EVD (7 items/4-point likert scale) (Appendix 1).

Sufficient time was given to respondents to read, comprehend and answer all the survey questions. Confidentiality was maintained throughout the study by not disclosing respondent's identity and requesting participants to provide honest answers.

\section{Inclusion and exclusion}

The study population included the clinical members of staff, namely, medical doctors, nurses, pharmacists, physiotherapists and laboratory technicians. The subjects who participated in the pilot study, and not willing to provide written consent to participate were excluded from the final sample.

\section{Ethical clearance}

The study protocol was approved by the Institutional Review Board (IRB), University

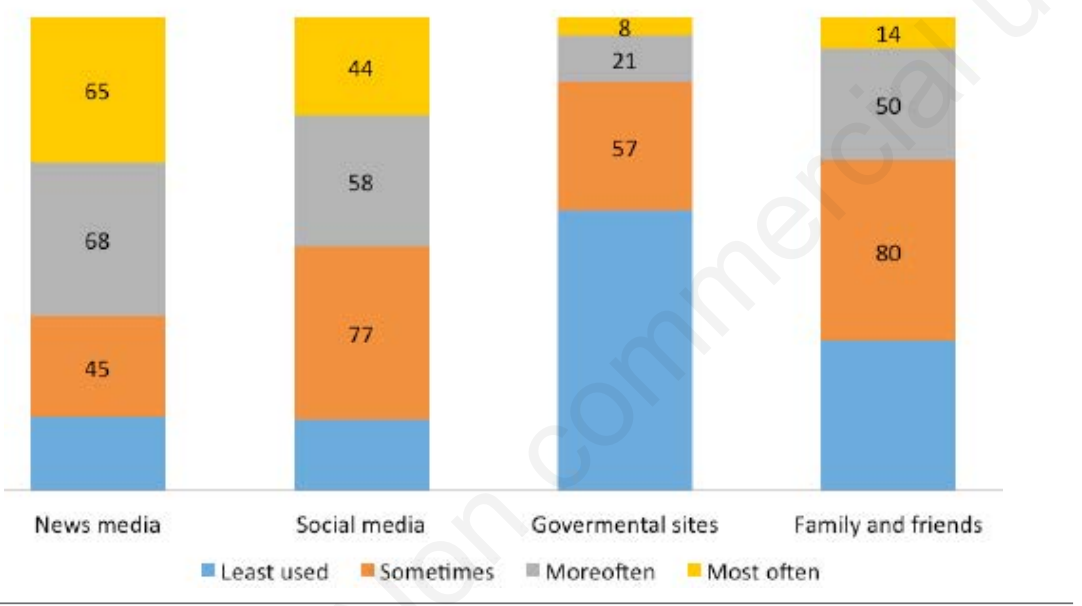

Figure 1. Source of Ebola virus disease information. of Gondar-School of Pharmacy. A written informed consent was also obtained from each HCP willing to participate in the study.

\section{Data analysis}

Data analysis was performed using SPSS (version 22; IBM, Armonk, NY, USA). Descriptive analysis was applied to calculate the frequencies and percentages. Binary logistic regression were computed to examine the level of association among variables. A P-value of less than 0.05 was considered statistically significant.

\section{Results}

A total of 245 HCPs were approached, of which 211 completely filled the study questionnaire $(86.1 \%$ response rate), including 168 (79.6\%) men and 43 (20.4\%) women. The majority of respondents were doctors $(n=99$, $46.9 \%$ ), and most (51.6\%) were between 20 to 25 years with a mean age of $24.5 \pm 2.57$ years (Table 1).

\section{Awareness and knowledge}

Table 2 shows awareness and knowledge about EVD. The vast majority had heard about EVD, and were afraid of getting EVD (78.2\%). However, over $55 \%$ of respondents attended the lectures/discussion related to EVD at Gondar University. The main source of information about EVD was the news media (TV/video, magazines, newspapers and radio) (Figure 1). Official governmental websites were the least-reported sources of information. Moreover, $38 \%$ of the respondents sometimes discussed EVD-related topics with family and friends. Only seventy one (33.6\%; $\mathrm{P}=0.045$ ) participants were able to correctly identify the first EVD case reported in West Africa in 2013, and fruit bats as reservoirs $[58.7 \% ; \quad 0 \mathrm{R}=0.378, \quad 95 \% \mathrm{CI}=0.218-0.664$;

Table 1. Socio-demographic characteristics of study participants $(\mathrm{N}=211)$.

$\begin{array}{lc}\text { Characteristics } & \text { Participants (\%) } \\ \text { Sex } & \\ \text { Male } & 168(79.6) \\ \text { Female } & 43(20.4) \\ \text { Age } & 109(51.6) \\ 20-25 & 79(37.4) \\ 26-30 & 23(10.9) \\ >30 & \\ \text { Profession } & 99(46.9) \\ \text { Doctors } & 62(29.3) \\ \text { Nurses } & 33(15.6) \\ \text { Pharmacists } & 17(8.0) \\ \text { Other } & \end{array}$

Figure 2. Ebola virus disease symptoms identified by the respondents.

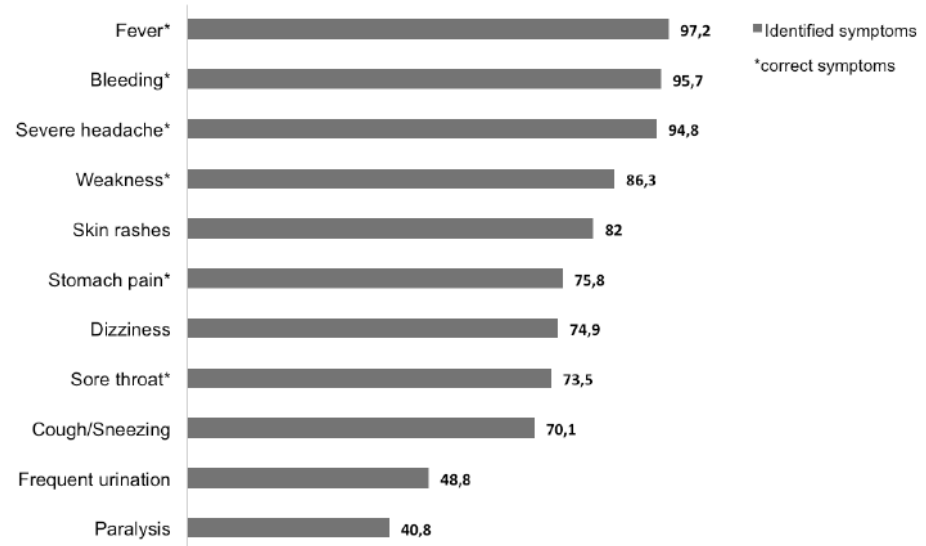


$\mathrm{P}=0.001$ ]. Sixty (28.4\%) thought EVD can be treated with antibiotics, causes paralysis like polio (45\%) and correctly identified that an infected person does not show any signs and symptoms for up to 21 days (77.5\%) (Table 2). In addition, the majority of the respondents also identified EVD symptoms correctly, such as fever (97.2\%), bleeding (95.7\%), severe headache $(94.8 \%)$, body weakness $(86.3 \%)$, stomach pain (75.8\%) and sore throat (73.5\%) (Figure 2).

A majority of HCPs knew that the EVD can be transmitted through body fluids of an infected person, objectives and materials contaminated by infected person and dead bodies of EVD victims, and asymptomatic person in the community (86.2\%). But many believed that EVD can be transmitted through food/water

Table 2. Awareness and knowledge of health professionals towards Ebola virus $(\mathrm{N}=\mathbf{2 1 1})$.

\begin{tabular}{|c|c|c|c|c|c|}
\hline \multirow[t]{2}{*}{ Questions } & \multicolumn{2}{|c|}{ Profession } & \multirow{2}{*}{$\begin{array}{l}\text { Total, } \\
\text { N (\%) }\end{array}$} & \multirow{2}{*}{$\begin{array}{c}\text { OR } \\
(95 \% \mathrm{CI})\end{array}$} & \multirow[t]{2}{*}{ P-value } \\
\hline & $\begin{array}{c}\text { Doctors } \\
(\mathrm{N}=99) \mathrm{N}(\%)\end{array}$ & $\begin{array}{l}\text { Allied health } \\
\text { professionals } \\
(\mathrm{N}=112) \mathrm{N}(\%)\end{array}$ & & & \\
\hline \multicolumn{6}{|c|}{ Awareness } \\
\hline $\begin{array}{l}\text { Have you heard of Ebola virus disease? } \\
\text { Yes } \\
\text { No }\end{array}$ & $\begin{array}{l}98(99) \\
1(1)\end{array}$ & $\begin{array}{c}106(94.6) \\
6(5.4)\end{array}$ & $\begin{array}{c}204(96.7) \\
7(3.3)\end{array}$ & $0.66(0.26-1.18)$ & 0.81 \\
\hline $\begin{array}{l}\text { How afraid are you of getting Ebola virus disease? } \\
\text { Not at all afraid } \\
\text { Somewhat afraid } \\
\text { Very afraid }\end{array}$ & $\begin{array}{l}21(21.2) \\
30(30.3) \\
48(48.5)\end{array}$ & $\begin{array}{l}25(22.3) \\
16(14.3) \\
71(63.4)\end{array}$ & $\begin{array}{l}46(21.8) \\
46(21.8) \\
119(56.4)\end{array}$ & $\begin{array}{l}1.242(0.626-2.468) \\
2.773(1.365-5.634) \\
1\end{array}$ & $\begin{array}{l}0.535 \\
0.005\end{array}$ \\
\hline $\begin{array}{l}\text { Did you attend any of the lectures/discussions about Ebola virus disease in university } \\
\text { Yes } \\
\text { No }\end{array}$ & $\begin{array}{l}48(48.5) \\
51(51.5)\end{array}$ & $\begin{array}{l}68(60.7) \\
44(39.3)\end{array}$ & $\begin{array}{c}116(55) \\
95(45)\end{array}$ & $\begin{array}{c}0.680(0.261-1.769) \\
1\end{array}$ & 0.076 \\
\hline \multicolumn{6}{|c|}{$\begin{array}{ll}\text { Knowledge } & \text { Ko }\end{array}$} \\
\hline $\begin{array}{l}\text { The first diagnosed Ebola virus disease case in the west Africa occurred in } 2013 \\
\text { True }^{\circ} \\
\text { False }\end{array}$ & $\begin{array}{l}26(26.26) \\
73(73.74)\end{array}$ & $\begin{array}{l}45(40.18) \\
67(59.82)\end{array}$ & $\begin{array}{l}71(33.65) \\
140(66.35)\end{array}$ & $\begin{array}{c}1.448(0.813-2.581) \\
1\end{array}$ & 2.09 \\
\hline $\begin{array}{l}\text { Fruit bats are the natural reservoir host for Ebola virus } \\
\text { True }^{\circ} \\
\text { False }\end{array}$ & $\begin{array}{l}63(63.64) \\
36(36.36)\end{array}$ & $\begin{array}{l}61(54.46) \\
51(45.54)\end{array}$ & $\begin{array}{l}124(58.77) \\
87(41.23)\end{array}$ & $\begin{array}{c}0.378(0.218-0.665) \\
1\end{array}$ & $0.001^{*}$ \\
\hline $\begin{array}{l}\text { Ebola can be treated with antibiotics in hospital } \\
\text { True } \\
\text { False }^{\circ}\end{array}$ & $\begin{array}{l}34(34.34) \\
65(65.66)\end{array}$ & $\begin{array}{l}26(23.21) \\
86(76.79)\end{array}$ & $\begin{array}{l}60(28.44) \\
151(71.56)\end{array}$ & $\begin{array}{c}0.556(0.301-1.029) \\
1\end{array}$ & 0.061 \\
\hline $\begin{array}{l}\text { Ebola can cause paralysis like polio } \\
\text { True } \\
\text { False }^{\circ}\end{array}$ & $\begin{array}{l}55(55.56) \\
44(44.44)\end{array}$ & $\begin{array}{l}40(35.71) \\
72(64.29)\end{array}$ & $\begin{array}{c}95(45.02) \\
116(54.98)\end{array}$ & $\begin{array}{c}1.22(0.696-2.070) \\
1\end{array}$ & 0.511 \\
\hline $\begin{array}{l}\text { A person with Ebola may show no symptoms for up to } 21 \text { days } \\
\text { True }{ }^{\circ} \\
\text { False }\end{array}$ & $\begin{array}{l}84(84.85) \\
15(15.15)\end{array}$ & $\begin{array}{l}80(71.43) \\
32(28.57)\end{array}$ & $\begin{array}{l}164(77.56) \\
47(22.27)\end{array}$ & $\begin{array}{c}0.808(0.422-1.546) \\
1\end{array}$ & 0.519 \\
\hline \multicolumn{6}{|c|}{ Mode of transmission } \\
\hline $\begin{array}{l}\text { Body fluids of an infected person } \\
\text { True }^{\circ} \\
\text { False }\end{array}$ & $\begin{array}{l}99(100) \\
0(0)\end{array}$ & $\begin{array}{c}109(97.32) \\
03(2.68)\end{array}$ & $\begin{array}{c}208(98.58) \\
03(1.42)\end{array}$ & $\begin{array}{c}0.437(0.390-4.893) \\
1\end{array}$ & 0.502 \\
\hline $\begin{array}{l}\text { Objects and materials contaminated with body fluids of an infected person } \\
\text { True }^{\circ} \\
\text { False }\end{array}$ & $\begin{array}{c}97(97.98) \\
2(2.02)\end{array}$ & $\begin{array}{c}105(93.75) \\
07(6.25)\end{array}$ & $\begin{array}{c}202(95.73) \\
09(4.27)\end{array}$ & $\begin{array}{c}0.517(0.123-2.223) \\
1\end{array}$ & 0.376 \\
\hline $\begin{array}{l}\text { Infected animals } \\
\text { True }^{\circ} \\
\text { False }\end{array}$ & $\begin{array}{l}80(80.80) \\
19(19.19)\end{array}$ & $\begin{array}{l}88(78.57) \\
24(21.43)\end{array}$ & $\begin{array}{l}168(79.62) \\
43(20.38)\end{array}$ & $\begin{array}{c}1.021(0.522-1.998) \\
1\end{array}$ & 0.952 \\
\hline $\begin{array}{l}\text { Dead bodies of an Ebola victim } \\
\text { True }^{\circ} \\
\text { False }\end{array}$ & $\begin{array}{l}99(100) \\
0(0)\end{array}$ & $\begin{array}{l}97(86.61) \\
15(13.39)\end{array}$ & $\begin{array}{c}196(92.89) \\
15(7.11)\end{array}$ & $\begin{array}{c}0.416(0.137-1.262) \\
1\end{array}$ & 0.121 \\
\hline $\begin{array}{l}\text { General Food/water } \\
\text { True } \\
\text { False }^{\circ}\end{array}$ & $\begin{array}{l}50(50.50) \\
49(49.49)\end{array}$ & $\begin{array}{l}64(57.14) \\
48(42.86)\end{array}$ & $\begin{array}{c}114(54.03) \\
97(45.97)\end{array}$ & $\begin{array}{c}0.519(0.300-0.899) \\
1\end{array}$ & $0.019^{*}$ \\
\hline $\begin{array}{l}\text { Mosquitoes or other insects } \\
\text { True } \\
\text { False }^{\circ}\end{array}$ & $\begin{array}{l}18(18.18) \\
81(81.81)\end{array}$ & $\begin{array}{l}34(30.36) \\
78(69.64)\end{array}$ & $\begin{array}{c}52(24.29) \\
159(75.71)\end{array}$ & $\begin{array}{c}0.781(0.415-1.469) \\
1\end{array}$ & 0.443 \\
\hline $\begin{array}{l}\text { Infected persons without symptoms in community } \\
\text { True }^{\circ} \\
\text { False }\end{array}$ & $\begin{array}{l}88(88.89) \\
11(11.11)\end{array}$ & $\begin{array}{l}94(83.93) \\
18(16.07)\end{array}$ & $\begin{array}{l}182(86.26) \\
29(13.74)\end{array}$ & $\begin{array}{c}1.297(0.586-2.871) \\
1\end{array}$ & 0.521 \\
\hline
\end{tabular}

${ }^{*} \mathrm{P}<0.05$ considered as statistically significant, ${ }^{\circ}$ appropriate answers, $\mathrm{OR}=$ odds ratio, $95 \% \mathrm{Cl}=$ confidence interval 
$[54 \% ; \quad(\mathrm{OR}=0.519, \quad 95 \% \mathrm{CI}=0.300-0.899)$

$\mathrm{P}=0.019$ ], or mosquitoes (24.3\%) (Table 2).

\section{Beliefs}

Nearly ninety-percent of HCPs thought EVD patients needed intensive care, and only $33.6 \%$ believed that the EVD epidemic can be controlled in the Ethiopia (33.6\%). In addition, more than half of the respondents thought that EVD was curable $[\mathrm{OR}=1.345,95 \% \mathrm{CI}=0.609$ 2.968 ], but some HCPs [ $28 \% ; 0 \mathrm{R}=2.265$, $95 \% \mathrm{CI}=0.782-6.654]$ believed EVD is a punishment from God (Table 3 ).

\section{Perception and attitudes}

Ninety eight (46.5\%) HCPs strongly agreed that they feel angry/afraid to interact with an EVD infected person $(\mathrm{P}=0.006)$. The majority of the respondents $(66.8 \%)$ recommended that the EVD infected patients should be separated and to be treated separately, in order to protect the community. Interestingly, nearly half of the HCPs (48.3\%) declared that they feel uncomfortable if any of their family members or friends get infected with EVD $(\mathrm{P}=0.003)$ and EVD infected families should be isolated from the community $(34.6 \% ; \mathrm{P}=0.010)$. One hundred and eighteen HCPs (55.9\%) stated that they would feel uncomfortable (somewhat agree or strongly agree) to work in Ebola treating hospitals. A list of questions with the percentage of each response is provided in Table 4.

\section{Attitude}

More than half of the HCPs (54\%) believed that Ebola effected countries should close their airports to prevent transmissions and 38\% were more concerned of HIV in Ethiopia than EVD in West Africa. In addition, ninety-five percent of respondents disagreed (strongly dis-

Table 3. Health professionals' beliefs towards Ebola virus infection $(\mathrm{N}=211)$.

\begin{tabular}{|c|c|c|c|c|c|}
\hline \multirow[t]{2}{*}{ Questions } & \multicolumn{2}{|c|}{ Profession } & \multirow{2}{*}{$\begin{array}{l}\text { Total, } \\
\text { N (\%) }\end{array}$} & \multirow{2}{*}{$\begin{array}{c}\text { OR } \\
(95 \% \mathrm{CI})\end{array}$} & \multirow[t]{2}{*}{ P-value } \\
\hline & $\begin{array}{c}\text { Doctors } \\
(\mathrm{N}=99) \mathrm{N}(\%)\end{array}$ & $\begin{array}{l}\text { Allied health } \\
\text { professionals } \\
(\mathrm{N}=112) \mathrm{N}(\%)\end{array}$ & & & \\
\hline \multicolumn{6}{|c|}{ Beliefs } \\
\hline $\begin{array}{l}\text { Ebola is a punishment from God? } \\
\text { True } \\
\text { False }^{\circ}\end{array}$ & $\begin{array}{l}20(20.20) \\
79(79.80)\end{array}$ & $\begin{array}{l}39(34.82) \\
73(65.18)\end{array}$ & $\begin{array}{c}59(27.97) \\
152(72.03)\end{array}$ & $\begin{array}{c}2.265(0.782-6.654) \\
1\end{array}$ & 0.132 \\
\hline $\begin{array}{l}\text { Ebola is due to government failure } \\
\text { True } \\
\text { False }^{\circ}\end{array}$ & $\begin{array}{l}36(36.36) \\
63(63.64) \\
\end{array}$ & $\begin{array}{l}45(40.18) \\
67(59.82)\end{array}$ & $\begin{array}{c}81(38.39) \\
130(61.61) \\
\end{array}$ & $\begin{array}{c}0.429(0.190-0.968) \\
1 \\
\end{array}$ & $0.042^{*}$ \\
\hline $\begin{array}{l}\text { There is a cure for Ebola } \\
\text { True } \\
\text { False }^{\circ}\end{array}$ & $\begin{array}{l}40(40.40) \\
59(59.60)\end{array}$ & $\begin{array}{l}72(64.29) \\
40(35.71)\end{array}$ & $\begin{array}{c}112(53.08) \\
99(46.92)\end{array}$ & $\begin{array}{c}1.345(0.609-2.968) \\
1\end{array}$ & 0.067 \\
\hline $\begin{array}{l}\text { Ethiopia can control Ebola epidemics at this moment } \\
\text { True } \\
\text { False }\end{array}$ & $\begin{array}{l}24(24.24) \\
75(75.76)\end{array}$ & $\begin{array}{l}47(41.96) \\
65(58.04)\end{array}$ & $\begin{array}{c}71(33.65) \\
140(66.35)\end{array}$ & $\begin{array}{c}1.286(0.580-2.853) \\
1\end{array}$ & 0.072 \\
\hline $\begin{array}{l}\text { Ebola patients need more intensive care } \\
\text { True } \\
\text { False }\end{array}$ & $\begin{array}{l}88(88.89) \\
11(11.11) \\
\end{array}$ & $\begin{array}{c}101(90.18) \\
11(9.82)\end{array}$ & $\begin{array}{l}189(89.57) \\
22(10.43)\end{array}$ & $\begin{array}{c}0.963(0.562-1.86) \\
1\end{array}$ & 0.274 \\
\hline
\end{tabular}

${ }^{*} \mathrm{P}<0.05$ considered as statistically significant, ${ }^{\circ}$ appropriate answers, $\mathrm{OR}=$ odds ratio, $95 \% \mathrm{Cl}=$ confidence interval

Table 4. Health professionals' perception and attitudes of Ebola virus disease.

\begin{tabular}{|c|c|c|c|c|c|}
\hline & $\begin{array}{l}\text { Strongly } \\
\text { disagree }\end{array}$ & $\begin{array}{c}\text { Some } \\
\text { what disagree }\end{array}$ & $\begin{array}{l}\text { Somewhat } \\
\text { agree }\end{array}$ & $\begin{array}{l}\text { Strongly } \\
\text { agree }\end{array}$ & P-value \\
\hline \multicolumn{6}{|l|}{ Perceptions } \\
\hline Feel angry and afraid if anyone I know is infected with Ebola. & $34(16.11)$ & $28(13.27)$ & $51(24.17)$ & $98(46.45)$ & 0.006 \\
\hline Ebola infected Individuals should be legally separated from others to protect the public. & $16(7.58)$ & $21(9.95)$ & $33(15.64)$ & $141(66.82)$ & 0.098 \\
\hline Ebola infected individuals names should be made public so that others can avoid them. & $87(41.23)$ & $55(26.07)$ & $37(17.54)$ & $32(15.17)$ & 0.159 \\
\hline Ebola patients should be treated separately. & $10(4.74)$ & $22(10.43)$ & $38(18.01)$ & $141(66.82)$ & 0.336 \\
\hline Feel uncomfortable if any of patients, family members or friends are infected with Ebola. & $29(13.74)$ & $32(15.17)$ & $48(22.75)$ & $102(48.34)$ & 0.003 \\
\hline Ebola infected families should be isolated from community. & $42(19.91)$ & $43(20.38)$ & $53(25.12)$ & $73(34.6)$ & 0.010 \\
\hline Uncomfortable to work in hospital treating Ebola patients. & $48(22.75)$ & $45(21.33)$ & $74(35.07)$ & $44(20.85)$ & 0.250 \\
\hline \multicolumn{6}{|l|}{ Attitudes } \\
\hline Ebola effected countries should close airports to prevent transmissions. & $60(28.4)$ & $37(17.5)$ & $58(27.4)$ & $56(26.5)$ & 0.053 \\
\hline Ebola is like any infectious diseases affecting the world. & $147(69.67)$ & $53(25.12)$ & $7(3.32)$ & $4(1.90)$ & 0.183 \\
\hline Ebola epidemics can be controlled easily & $96(45.5)$ & $65(30.81)$ & $39(18.48)$ & $11(5.21)$ & 0.752 \\
\hline HIV is bigger threat than Ebola in Africa. & $71(33.65)$ & $53(25.12)$ & $58(27.49)$ & $29(13.74)$ & 0.090 \\
\hline I am more concerned about my life than treating Ebola patients. & $66(31.28)$ & $72(34.12)$ & $48(22.75)$ & $25(11.85)$ & 0.129 \\
\hline I am more concerned about HIV in Ethiopia than Ebola in West Africa. & $65(30.81)$ & $66(31.28)$ & $50(23.70)$ & $30(14.22)$ & 0.129 \\
\hline If available, I advise all the patients to take Ebola vaccine & $38(18.01)$ & $34(16.11)$ & $38(18.01)$ & $101(47.87)$ & $0.010^{*}$ \\
\hline
\end{tabular}

*Statistically significant at $\mathrm{P}<0.05$ (chi-square analysis) 
agree or somewhat disagree) that EVD is like other infectious diseases affecting the world. More than forty percent of the respondents believed HIV to be a bigger threat to Africa than Ebola $(\mathrm{P}>0.05)$. However, one hundred and thirty nine $(65.8 \%)$ agreed that they will advise all the patients to take Ebola vaccine, if readily available $(\mathrm{P}=0.010)$ (Table 4$)$.

\section{Discussion}

This is the first report on the knowledge, attitudes and perceptions among Ethiopian HCPs about EVD. Our study revealed GUH healthcare professionals have insufficient knowledge, beliefs and perceptions but showed positive attitude to advise Ebola vaccine to all, if made available.

Overall, the majority of HCPs working in GUH heard about EVD, but $57.8 \%$ were very afraid of getting EVD $(\mathrm{P}=0.001)$ after attending EVD awareness lectures/discussion in the university. Similar knowledge was also reported in United States (U.S) doctors (62.3\%). ${ }^{17}$ It is arguable, that HCPs fear of getting EVD could lead to adverse consequences if a similar outbreak occurs particularly in Gondar city, which in turn may worsen the dynamics of patient care during potential outbreaks.

In this study, more than half (51.6\%) of respondents relied on mass media and social media for obtaining Ebola related information. Similar findings were noticed from previous studies conducted with students, ${ }^{11,18}$ the general public, ${ }^{10,12-14}$ Australian Hajj pilgrims', ${ }^{19}$ and HCPs. ${ }^{16,20,21}$ HCPs' role is crucial in spreading and increasing awareness of acute fatal EVD to patients and community. However, government websites were least used to access Ebola information, comparably lower than University of California students (12\%).

Significant knowledge gaps were noted among HCPs, particularly not being aware of the first case of the EVD outbreak reported in West Africa (33.6\%). In addition, many doctors had inadequate knowledge that EVD can cause paralysis like polio and can be treated with antibiotics. These results were discouraging since GUH has invested a significant amount of resources to educate medical staff to improve their knowledge about EVD. In depth qualitative studies are important to understand the underlying reasons for this poor knowledge among doctors.

HCPs did have good knowledge about modes of transmission and identifying EVD symptoms compared to other studies. ${ }^{16-18,21-24}$ But the majority (54\%) of respondents believed that EVD can be transmitted through food, water, mosquitoes or other insects (24.6\%).This was much higher than findings in Nigerian patients attending family practice setting
$(8 \%)^{13}$ and Sudan health care providers (20.2\%), ${ }^{16}$ but lower than Indian dental practitioners $(37 \%)^{23}$ and U.S college students (31\%). ${ }^{11}$ However, special emphasis should be taken through interactive trainings focusing on broad principles towards infection control in clinical settings. This can serve as generic model for improving knowledge and resolve misconceptions towards majority of infectious diseases. Furthermore, our respondents also showed discrepancies in their perceptions. For instance, $66.8 \%$ of the HCPs felt angry/afraid to know about Ebola affected patients and 48.3\% felt uncomfortable to know if any of the patients and their family members or friends were infected with Ebola. In addition, they also thought that Ebola infected families should be separated from the community, which may reflect differences in their perceptions to admit themselves for socially desirable opinions. Similar results were identified in studies conducted elsewhere. ${ }^{16,17,22,24}$ Finally, a majority of the respondents would like to recommend Ebola vaccine if made available in Ethiopia and strongly expressed that Ebola is not like any other infectious disease affecting the world (69.6\%), which implies their positive attitudes to Ebola prevention.

\section{Limitations}

This study had some limitations that should be considered. This was a cross-sectional survey conducted on single health facility and the results might not be generalizable to HCPs working in other hospitals in Amhara state, Ethiopia. In addition, data presented in this study are self-reported partly depending on respondents' honesty and ability to recall. Some of the respondents may have provided more extreme responses than others, due to beliefs and motivations, and might be subjected to recall bias.

Despite the limitations, our findings provided a valuable insight, providing some important information about the understanding of HCPs about Ebola in Ethiopia compared to other relevant studies.

\section{Conclusions}

Our study found significant information gaps constituting poor EVD knowledge with serious misconceptions among doctors compared to allied health professionals. All HCPs had incorrect perceptions of EVD, but also positive attitude towards EVD. In view of this, we recommend more intensive training of all HCPs working in GUH.

\section{References}

1. E. Sterk, MSF Ebola \& Marburg Outbreak Control Guidance Manual, 2008.

2. Centers for Disease Control and Prevention. About Ebola virus disease. Available from: http://www.cdc.gov/vhf/ebola/about.html. Accessed October 28, 2015.

3. World Health Organization, Governments of Guinea, Liberia, and Sierra Leone. Ebola virus disease: outbreak response plan in West Africa. Available from: http://www.who.int/csr/disease/ebola/evdoutbreak-response-plan-westafrica2014.pdf/. Accessed July 6, 2015.

4. Kilmarx PH, Clarke KR, Dietz PM, et al. Ebola virus disease in health care workers-Sierra Leone, 2014. MMWR Morb Mortal Wkly Rep 2014;63:1168-71.

5. Kerstiens B, Matthys F. Interventions to control virus transmission during an outbreak of Ebola hemorrhagic fever: experience from Kikwit, Democratic Republic of Congo, 1995. J Infect Dis 1999:179:S263-7.

6. World Health Organization. Ebola strategy: Ebola and Marburg virus disease epidemics: preparedness, alert, control, and evaluation. Available from: http:// www.who.int/csr/disease/ebola/manual_E VD/en/. Accessed September 5, 2015.

7. World Health Organization. Health worker Ebola infections in Guinea, Liberia and Sierra Leone. Available from: http://www.who.int/csr/resources/publications/ebola/health-workers-infections/en. htmlAccessed September 28, 2015.

8. World Health Organization. Ebola preparedness continues in Ethiopia. Available from: http://www.afro.who.int/en/ethiopia/ press-materials/items/7227-ebola-preparedness-continues-in-ethiopia.html. Accessed October 10, 2015.

9. UNFPA. Summary and Statistical Report of the 2012 Population and Housing Census of Ethiopia. Ethiopia: UNFPA; 2012:10-16.

10. Kobayashi M, Beer KD, Bjork A, et al. Community knowledge, attitude, and practices regarding Ebola virus disease (EVD)five counties, Liberia, September-October, 2014. MMWR Morb Mortal Wkly Rep 2015;64:714-8.

11. Koralek T, Brown B, Runnerstrom MG. Assessing the level of knowledge, attitude, and beliefs about Ebola virus disease among college students. Am J Infect Control 2015;43:1143-5

12. Steel Fisher GK, Blendon RJ, LasalaBlanco N. Ebola in the United States: Public reactions and implications. $\mathrm{N}$ Eng $\mathrm{J}$ Med 2015;373:789-91.

13. Shittu RO, Sanni MA, Odeigah LO, et al. Awareness, Knowledge and 
Misconceptions about Ebola Virus Disease (EVD) in a Family Practice Setting in Nigeria, West Africa. J Antivir Antiretrovir 2015;7:10-4.

14. Gidado S, Oladimeji AM, Roberts AA, et al. Public knowledge, perception and source of information on Ebola virus diseaseLagos, Nigeria: September, 2014. PLoS Curr 2015;8:7.

15. Lliyasu G, Ogoina D, Otu AA, et al. A multisite knowledge attitude and practice survey of Ebola virus disease in Nigeria. PLoS One 2015;10:e0135955.

16. Alfaki MM, Salih AM, Elhuda DA, Egail MS. Knowledge, attitude and practice of health care providers towards Ebola virus disease in hotspot in Khartoum and White Nile states, Sudan, 2014. Am J Infect Control 2015. [Ahead of Print].

17. Ganguli I, Chang Y, Weissman A, et al.
Ebola risk and preparedness: a national survey of interns. J Gen Intern Med 2015. [Ahead of Print].

18. Rosengard D, Tucker-McLaughlin M, Brown T. Students and social news: how college students share news through social media. ENews 2014;8:120-37.

19. Alqahtani AS, Wiley KE, Willaby HW, et al. Australian Hajj pilgrims' knowledge, attitude and perception about Ebola, November 2014 to February 2015. Euro Surveill 2015;20:21072.

20. Raghavendra Vailaya CG, Kumar S, Moideen S. Ebola virus disease: knowledge, attitude, practices of health care professionals in a tertiary care hospital. J Pub Health Med Res 2014;2:13-8.

21. Olowookere SA, Abioye-Kuteyi EA, Adepoju $\mathrm{OK}$, et al. Knowledge, attitude, and practice of health workers in a tertiary hospital in Ile-Ife, Nigeria, towards Ebola virus disease. J Trop Med 2015:431317.

22. Oladimeji AM, Gidado S, Nguku P, et al. Ebola virus disease-gaps in knowledge and practice among healthcare workers in Lagos, August 2014. Trop Med Int Med 2015;20:1162-70.

23. Gupta N, Mehta N, Gupta P, et al. Knowledge regarding Ebola Hemorrhagic Fever among private dental practitioners in Tricity, India: a cross-sectional questionnaire study. Niger Med J 2015;56:13842.

24. Fazekas B, Fazekas J, Moledina M, et al. Ebola virus disease: awareness among junior doctors in England. J Hosp Infect 2015. [Ahead of Print].

25. Amhara National Regional State Health Bureau (ANRSHB): Annual Report. Bahir Dar: ARHB; 2012. 